\title{
BIOFILM-RELATED INFECTIONS IN OPHTHALMOLOGY
}

\author{
MARK J. ELDER ${ }^{1,2}$, FIONA STAPLETON ${ }^{3}$, ELWYN EVANS ${ }^{2}$ and JOHN K. G. DART ${ }^{1,2}$ \\ London
}

\begin{abstract}
SUMMARY
A biofilm is a functional consortium of microorganisms organised within an extensive exopolymer matrix. Organisms within a biofilm are difficult to eradicate by conventional antimicrobial therapy and can cause indolent infections. This paper reviews the pathophysiology of biofilms and their application of ophthalmology. Under certain environmental conditions such as nutrient limitation, some bacteria may secrete and reside in an exopolysaccharide glycocalyx polymer. This confers relative protection from humoral and cellular immunity, antibiotics and surfactants. Biofilms occur in natural aquatic ecosystems, on ship hulls, in pipelines and on the surface of biomaterials. They cause clinical infections of prosthetic hip joints, heart valves and catheters. Biofilm formation may occur rapidly on contact lenses and their cases and hence contribute to the pathogenesis of keratitis. Formation of biofilms is also implicated in delayed post-operative endophthalmitis and crystalline keratopathy. Bacteria within biofilms are 20-1000 times less sensitive to antibiotic than free-living planktonic organisms. Existing experimental methods for modifying biofilm include the use of macrolide antibiotics that specifically impair biofilm production, and the use of enzymes to digest it. These may have clinical applications, as potential adjunctive therapies to antibiotic treatment, for these resistant infections. In conclusion, biofilm is an important cause of infections associated with biomaterials. Novel strategies are needed to deal with these.
\end{abstract}

Investigation of bacterial infection typically cultures bacteria in nutrient broths and agar plates. This ensures optimal and rapid growth which provides a prompt diagnosis and assessment of antibiotic sensitivities. However, bacteria rarely interact with

From: ${ }^{1}$ Moorfields Eye Hospital, London; ${ }^{2}$ Department of Clinical Science and Electron Microscopy Unit, Institute of Ophthalmology, London; ${ }^{3}$ Department of Optometry, City University, London, UK.

Correspondence to: Mr M. J. Elder, Moorfields Eye Hospital, City Road, London EC1V 2PD, UK. the environment under such growth conditions. Under suboptimal conditions they divide at a much slower rate and behave very differently. ${ }^{1-3}$ Often, they may secrete, and then reside in, a complex highly ordered extracellular polymer matrix: a biofilm. ${ }^{4} \quad$ The bacteria within this biofilm are relatively sequestered from antibiotics and the host's immune system and therefore may cause chronic infections. Biofilms have clinical relevance in all fields of medicine, especially with biomaterials such as prosthetic hip replacements, heart valves, intraocular lenses and contact lenses. Novel therapeutic strategies will be required to treat or prevent clinical infections due to biofilms.

\section{Pathogenic Mechanisms of Bacterial Disease}

Bacteria may interact with a host and cause disease by a variety of complex mechanisms. This may occur by the release of endotoxin and by the deleterious effects of the host response. These effects may be the result of bacterial multiplication in the tissues or on its surface. In order to colonise the host, the bacteria must first adhere to its surface and this requires a mechanism to maintain that bond..$^{5} \mathrm{~A}$ biofilm is one type of surface colonisation.

\section{Bacterial Adherence and Colonisation}

The first step towards adherence is that bacteria come sufficiently close to a surface, by either fluid or airborne mechanisms. Attraction or repulsion of the bacteria occurs due to the sum of the Van der Waals forces and electrostatic forces. This is a function of the distance from the surface, the size of the bacteria and the surface hydrophobicity. These interactions of total Gibbs energies are described by the Derjaguin-Landau and Verwey-Overbeek (DLVO) theory. ${ }^{6}$ The net result is usually a repulsive force. For a surface bathed in fluid, such as the conjunctiva or a contact lens, these forces are also dependent on the concentration of solutes in that solution and may 
become attractive with increasing ionic strength. Initial adhesion can easily be broken by mechanical forces or bacterial mobility. ${ }^{7}$

Once a bacterium is within $1 \mathrm{~nm}$ of a surface, adhesion is reinforced by hydrogen bonding and ion pairing. The bacterium then becomes anchored using pili and the secretion of adhesive exopolymers. Depending on the environmental conditions, the bacterium may produce an exopolymers. Depending on the environmental conditions, the bacterium may produce an exopolysaccharide glycocalyx polymer that coats itself and the surface. This is a biofilm. Excretion of the exopolymer depends on the type of bacterium, its growth phase, the nutrient status, the temperature, the presence of biocides, surface tension and the nature of the surface. ${ }^{8-10}$ Eventually, this glycocalyx becomes continuous, envelops many bacteria and ensures strong binding. ${ }^{11}$ Once cocooned in this slime layer, the bacteria behave differently from planktonic bacteria. ${ }^{4}$

\section{Biofilm Physiology}

A biofilm is defined as a functional consortium of microorganisms organised within an extensive exopolymer matrix. ${ }^{4}$ It is a microcosm within which bacteria replicate, existing either as clusters or as isolated units. Nutrients are relatively limited and therefore cell division is 5-15 times slower than under planktonic conditions. ${ }^{1-3}$

Antibody and bacteriophage access is limited to the bacteria. Consequently, bacteria within a biofilm are better able to survive attacks by white blood cells, bacteriophages, amoebae, antibiotics, biocides, surfactants and mechanical trauma. ${ }^{12-19}$ However, bacterial antigens may still present at the biofilm surface. The resultant antibody-antigen interaction may activate complement and initiate inflammation. ${ }^{20}$ This may damage the host tissue. Binding of fibrin and platelets may cause vegetations such as in endocarditis $^{21,22}$ and trapping of ions may lead to the production of infected stones such as occurs in the kidney or gall bladder. ${ }^{4,23}$

Therefore, a clinical infection that has evoked the formation of biofilm might be expected to be chronic, relatively resistant to antibiotics and may be polymicrobial. It may be culture negative unless the actual biofilm is sampled or there has been shedding of bacteria from the biofilm at the time of sampling. Dispersal of bacteria often corresponds to acute clinical exacerbations. ${ }^{4}$

\section{Shedding of Bacteria from a Biofilm}

Depending on the environmental conditions, bacterial replication may lead to shedding of bacteria from the biofilm. ${ }^{24}$ Cell division provides two genotypically identical but phenotypically different cells: mother and daughter cells. The shed daughter cells are particularly sensitive to antibiotics compared with the cells that remain within the biofilm. ${ }^{25,26}$ This is clinically relevant. Clinical attempts to isolate organisms maybe unsuccessful if shedding is intermittent. Further, antibiotic sensitivity testing of the shed daughter cells is different from that of the bacteria within the biofilm. ${ }^{26,27}$ Therefore, a bacteraemia may be successfully eradicated but the biofilm organisms may persist as a nidus of infection.

\section{Resistance to Antibiotics}

Biofilm-encased bacteria are relatively resistant to antibiotics and biocides. In vitro data show that the levels of antibiotic or biocides must be $20-1000$ times greater to achieve adequate growth inhibition in a biofilm compared with the same bacteria in a planktonic state. 16,17,28,29 $^{\text {This resistance is complex }}$ and not completely understood. There are three major mechanisms involved.

First, antibiotic or biocide access to the bacteria is limited. Theoretically this could be impaired by either diffusion, binding of the antibiotic or inactivation of the antibiotic. However, the diffusion coefficients of antibiotics are similar to that of aqueous solutions ${ }^{30,31}$ and the actual penetration of antibiotics is unimpaired by the biofilm. ${ }^{83}$ Selective binding of antibiotics by the exopolymers does occur and is significant for some antibiotics such as ciprofloxacin but not tobramycin. ${ }^{26,30-32}$ Bacteria may liberate enyzmes such as beta-lactamase that inactivate antibiotics. These enzymes are concentrated within the biofilm and this decreases the concentration of antibiotic adjacent to the bacteria. ${ }^{33}$ These last two factors are major contributors to the relative antibiotic resistance.

Second, nutrient availability within the biofilm may reduce the bacterial growth rate. This may cause the cells to adopt a different phenotype from that of planktonic growth. Both factors may alter the antibiotic sensitivity. ${ }^{10,34}$

Third, attachment to a surface may cause inducement and derepression of genes associated with a sessile existence. This may coincidentally alter antimicrobial sensitivity. Therapeuticaliy, interference with this process could prevent bacterial adherence or prevent further production of the biofilm matrix. ${ }^{35}$

\section{EXAMPLES OF IMPORTANT BIOFILM INTERACTIONS}

\section{Naturally Occurring Human Biofilms}

Naturally occurring biofilms are observed at the junction of mucous membranes and sterile body cavities: for example, the cervix and the distal urethra. ${ }^{36,37}$ Biofilm also occurs on teeth, ${ }^{8}$ where it is commonly known as plaque. Within the plaque, $\mathrm{pH}$ changes and liberation of enzymes enhance erosion 
of the tooth enamel (dental caries). Prevention of caries is usually achieved with mechanical debridement of the biofilm by brushing with an abrasive toothpaste, rather than with antibiotics.

\section{Environmental and Industrial Biofilms}

Bacteria occur naturally in rivers, lakes, oceans and sewage treatment plants. In these locations, growth as a biofilm is the preferred mode of existence. ${ }^{38}$ Massive accumulation of biofilm is called biofouling. This is important in reducing the efficiency of industrial heat exchangers, increasing drag on ship hulls and clogging pipes. ${ }^{4,5}$

Biofilm-related metal corrosion is a major industrial problem. It is responsible for the degradation of pipelines, such as the oil pipelines in Alaska, and corrosion of fuel tanks of commercial aircraft. ${ }^{16}$ The corrosion is due to anaerobic sulphate-reducing bacteria forming microscopic corrosion cells which cause electrolytic damage. ${ }^{39,40}$

\section{Biomaterials}

Biomaterials are man-made substances that are implanted into the human body: for example, intraocular lenses, prosthetic hip joint replacements and urinary catheters. Most are at some risk of infection, either acute or chronic. The chronic infections typically have acute relapses, are resistant to antibiotic therapy, may be polymicrobial and may be intermittently culture negative. Clinical cure often requires intensive antibiotics and removal of the prosthesis. These are the typical features of bacterial infection in the presence of a biofilm.

Biofilm may be visualised by electron microscopy when enhanced by staining with ruthenium red. ${ }^{41}$ Using this method, viable bacteria encased within a biofilm have been demonstrated from clinically infected cases of most biomaterials. This includes prosthetic hip joints, cardiac pacemakers, prosthetic heart valves, intravenous catheters of all types, urinary catheters, vascular prostheses, sutures, endotracheal tubes and intrauterine contraceptive devices. ${ }^{17,42-50}$ A similar situation exists for the sequestrum of bone in chronic osteomyelitis. ${ }^{51}$

\section{BIOFILM AND OPHTHALMOLOGY}

\section{Endophthalmitis (Fig. 1)}

Most cases of clinical endophthalmitis occurring after cataract surgery are due to bacteria entering the eye at the time of surgery. ${ }^{52-54}$ Gram-positive bacteria make up 76-90\% of the culture-positive cases of pseudophakic endophthalmitis and Staphylococcus epidermidis is cultured in $38-59 \% .{ }^{55-57}$ Under routine planktonic growth conditions, these bacteria grow quickly in the laboratory. This contrasts with the clinical presentation that often occurs late after surgery: $55 \%$ present more than 1 week after surgery and $20 \%$ present more than 2 months later. ${ }^{58}$ Vitreous cultures are positive in, at most, $75 \%{ }^{57}$ Because of electrostatic forces, bacteria adhere well to intraocular lenses. Simply wiping a lens around the wound during cataract surgery will cause $26 \%$ of lenses to have viable organisms attached. ${ }^{59}$ In vitro, $S$. epidermidis adheres firmly to polymethylmethacrylate (PMMA) within 1 hour and biofilm formation may be extensive within 16 hours. ${ }^{60}$ Staphylococci adhere better to polypropylene than to PMMA ${ }^{61}$ and there is epidemiological evidence for a 4.5 times increased risk of endophthalmitis for intraocular lenses (IOLs) with polypropylene haptics. ${ }^{62}$

In some cases, bacteria introduced at the time of surgery may become sequestered within a biofilm on the IOL, haptic or capsule. ${ }^{63}$ Bacteria would be shed intermittently causing uveitis. This concept has clinical significance. Using epidemiological data it has been estimated that avoidance of IOLs with polypropylene legs would reduce the number of cases of endophthalmitis in the United States from 1200 to 500 per annum. ${ }^{64}$

\section{Contact-Lens Associated Keratitis and Bacterial Biofilm (Figs. 2, 3)}

Contact-lens-associated keratitis is frequently associated with Pseudomonas aeruginosa. ${ }^{6-68}$ The causative organisms are often derived from contaminated lens care materials, manual or ocular contaminations. ${ }^{69,72}$ Bacteria living in a biofilm may be involved in the persistence of organisms in contact lens cases. ${ }^{71,72}$ This is probably a factor accounting for the high incidence of lens case contamination and apparent resistance to disinfectant systems. Although these are effective in vitro against organisms in planktonic growth they are likely to be less active against the same organisms in sessile, biofilmenclosed growth. Currently lens disinfectant systems are tested against organisms in planktonic growth only.

Biofilm formation on the surface of contact lenses provides a theoretical mechanism by which small numbers of organisms can survive and replicate on the lens surface. This provides an inoculum of organisms in prolonged contact with the cornea. In vitro studies have demonstrated active bacterial adherence to all types of contact lenses. ${ }^{70,73-75}$ Subsequent colonisation may lead to biofilm formation..$^{73,76-78}$ This may occur in vivo after 48 hours of continuous wear in humans ${ }^{76}$ and in an animal model after 3 days. ${ }^{79}$ Bacteria, arising in small numbers from environmental sources, may adhere to the lens whereas in the normal eye they are cleared by the ocular surface defence mechanisms. If these adherent bacteria develop a glycocalyx and colonise the lens surface their numbers can then amplify on the lens itself. Evidence to support this in vivo has come from 


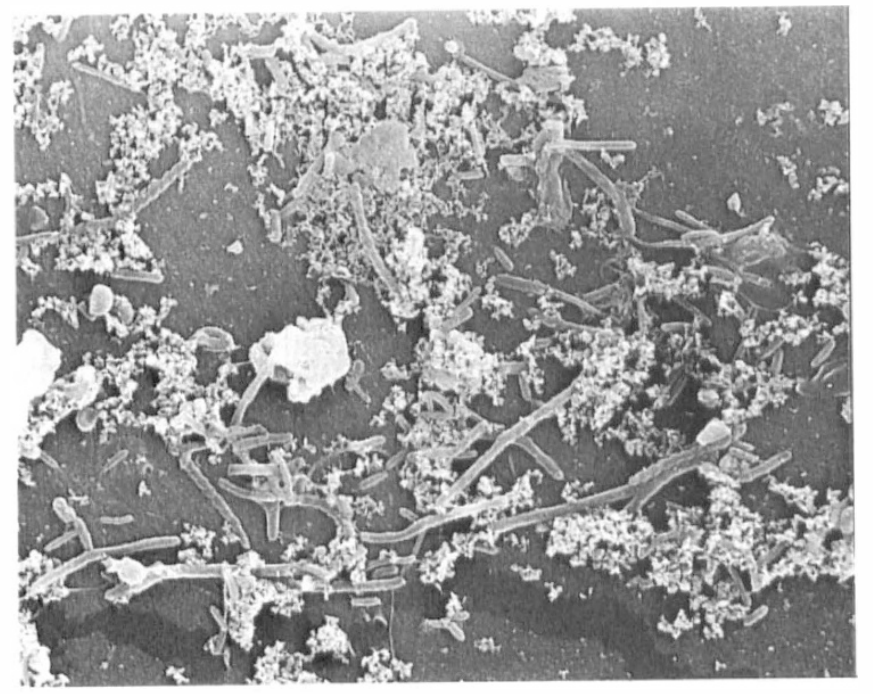

Fig. 1. Scanning electron micrograph taken at $\times 3000$ showing the surface of a polymethylmethacrylate intraocular lens (IOL) removed from a patient with late endophthalmitis. The micrograph shows spirochaete-like organisms associated with a thin fixed film of material on the surface of the IOL.

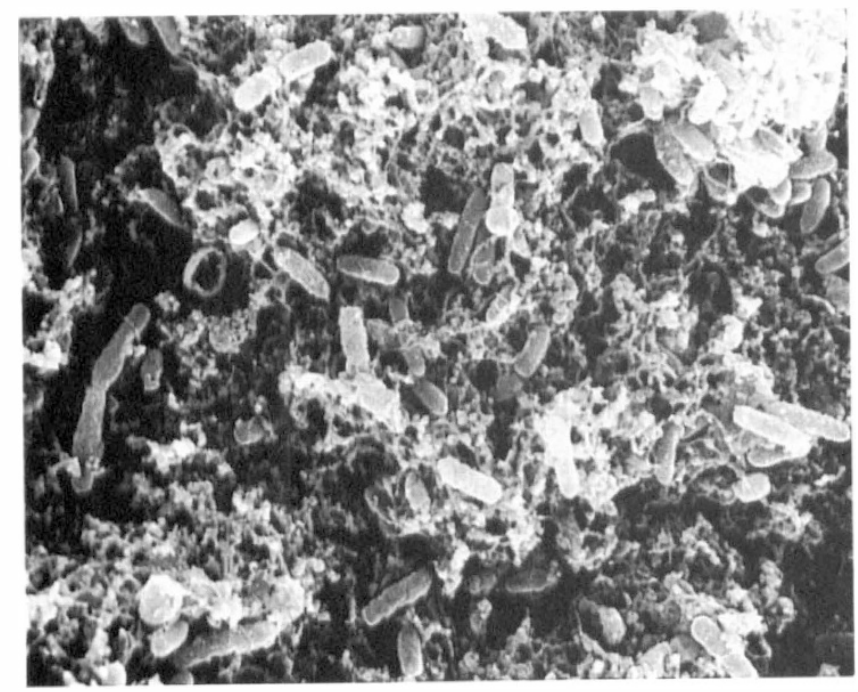

Fig. 3. Scanning electron micrograph (SEM) taken at $\times 5000$ showing the posterior surface of a worn hydrogel lens from a subject with culture-proven keratitis. Pseudomonas aeruginosa was recovered on culture from both the lens and cornea. SEM demonstrates adherent rod-shaped organisms embedded within a matrix of fixed material on the lens surface.

studies showing bacteria enclosed within a polysaccharide-rich matrix on lenses from wearers with culture-proven keratitis. $^{80,81}$

Epidemiological evidence for keratitis associated with soft contact lenses shows that the key risk factors are a lack of lens cleaning, poor disinfection and an extended wearing time. ${ }^{82}$ Risk is proportional to the length of continuous wearing time. This can be

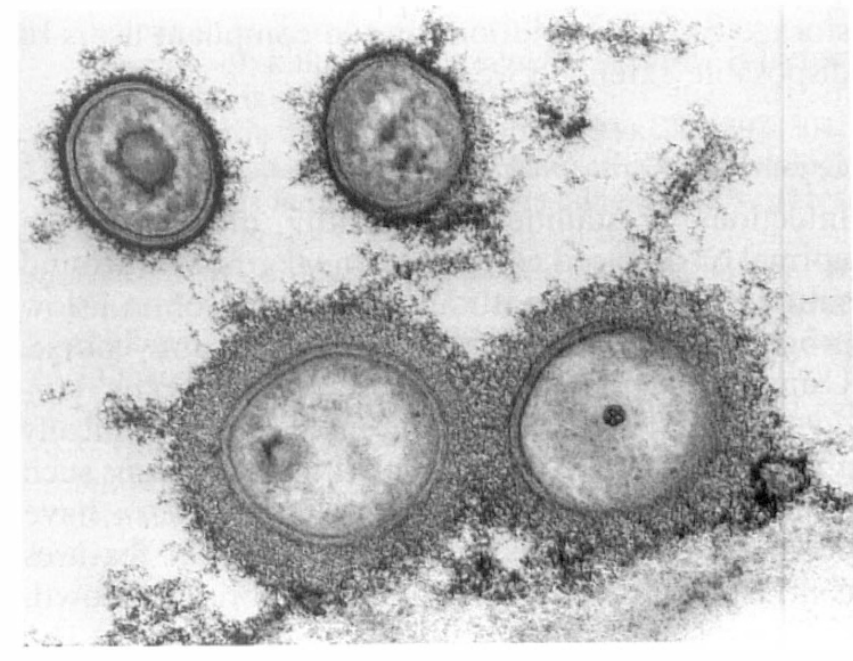

Fig. 2. Transmission electron micrograph (TEM) taken at $\times 60000$ showing organisms adherent to the posterior surface of a worn hydrogel contact lens, from a subject with culture-proven keratitis. Pseudomonas aeruginosa was recovered on culture from both the lens and cornea. TEM using ruthenium red stain demonstrates intact bacterial cell walls and intercellular components with extracellular polysaccharide-rich material between the lens and organisms.

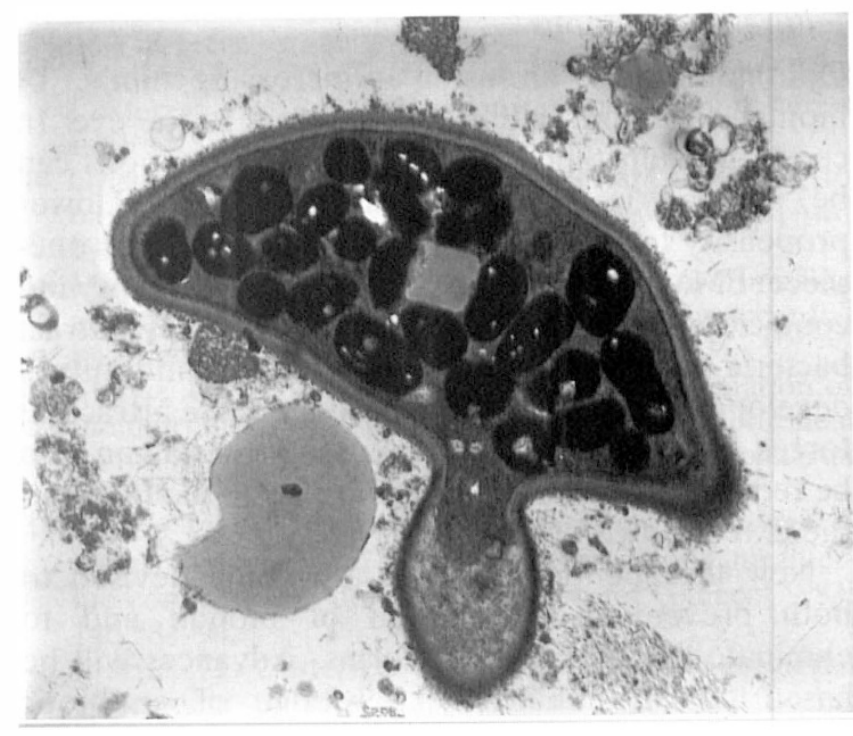

Fig. 4. Transmission electron micrograph showing an ultrathin corneal stromal section in crystalline keratopathy. Candida albicans was recovered on biopsy culture and the micrograph shows multiple blastophores surrounded by an extracellular matrix, possibly comprised of mucus or polysaccharide.

explained by the increasing amount of biofilm on the contact lens that provides a reservoir of bacteria.

These studies imply that contact lenses do provide a suitable substratum for bacterial adherence and biofilm formation. If a biofilm is relevant in human contact-lens-related infections, it may also provide one explanation for the pathogenesis of keratitis in subjects without bacterial contamination of the lens 
storage case and solutions and in compliant users of disposable extended wear lenses.

\section{Crystalline Keratopathy (Fig. 4)}

Infectious crystalline keratopathy may occur in normal or diseased corneas, corneal grafts or around sutures. ${ }^{84-86}$ The natural history is of a slow progression and a protracted treatment course. Using appropriate techniques, Streptococcus viridans is often grown from the areas of the clinically apparent crystals, ${ }^{84-92}$ although other organisms such as staphylococci, Candida and Enterobacter have been cultured. ${ }^{90,93,94}$ The indolent clinical features contrast with the organisms' rapid laboratory growth and typically good antibiotic sensitivities. The authors postulate that the clinical and pathological features can be explained by the formation of a biofilm on the corneal lamellae. This is in keeping with the potential response to sutures elsewhere in the body. ${ }^{43}$ Unfortunately, unless special techniques are employed, routine fixing for electron microscopy destroys any biofilm. ${ }^{4}$ Evidence for this hypothesis is awaited.

\section{Future Interventions}

Ophthalmologists are using an increasing number of biomaterials both within and external to the eye. In certain circumstances, biofilm-related infections can be reduced by using biomaterials with a lower propensity for biofilm formation. This includes onepiece PMMA IOLs and certain contact lens and contact lens case materials. IOLs actively attract bacteria during insertion into the eye and future developments may be able to reduce these attractant forces. Total numbers of adherent bacteria can also be reduced by avoiding contact between the IOL and the external eye during surgery.

New therapeutic strategies are being devised to both prevent the formation of biofilm and to eliminate the bacteria if it forms. Advances will be based on an enhanced knowledge of antibiotic performance and adequate laboratory testing methods specifically using biofilms. Further strategies may reduce antibiotic binding and enzymatic degradation within the biofilm, change nutrient availability to the bacteria and possibly alter gene expression so as to confer resistance. Work is already under way. For example, erythromycin actively inhibits glycoconjugate secretion in the lung and is clinically effective in panbronchiolitis at doses less than the MIC. ${ }^{95,96}$

This is due to its beneficial effects on preventing biofilm production. Clarithromycin, a macrolide antibiotic, also reduces the amount of biofilm present during infection. ${ }^{97}$ When combined with ofloxacin, an experimental model has shown that the reduction in biofilm significantly enhances the effects of the ofloxacin. ${ }^{97}$ Another approach is to digest the biofilm enzymatically. In animals with endocarditis, the addition of dextranase significantly enhanced penicillin sterilisation of the valves. ${ }^{98}$

These methods of inhibiting biofilm production, or exposing the organisms within it, offer potential adjuncts to antibiotic therapies for biofilm-mediated resistant infections. Novel strategies will be required to deal with bacterial biofilms as the use of biomaterials, and their associated problems, increases.

Key words: Biofilm, Contact lens, Endophthalmitis, Glycocalyx, Ruthenium red.

\section{REFERENCES}

1. Brock TD. Microbial growth rates in nature. Bacteriol Rev 1971;35:39-58.

2. Endy J, Burrows P. Generation times of Proteus mirabilis and Escherichia coli in experimental infections. Chemotherapy 1973;19:161-70.

3. Smith $H$. The mounting interest in bacterial and viral pathogenicity. Annu Rev Microbiol 1989;43:1-22.

4. Costerton JW, Cheng KJ, Geesey GG, Ladd TI, Nickel JC, Dasgupta M, Marrie TJ. Bacterial biofilms in nature and disease. Annu Rev Microbiol 1987; 41:435-64.

5. Marshall KC. Adsorption and adhesion processes in microbiological growth at interfaces. Adv Colloid Interface Sci 1986;25:59-86.

6. Rutter PR, Vincent B. Physico-chemical interactions of the substratum, microorganisms and the fluid phase. In Marshall KC, ed. Microbial adhesion and aggregation. Berlin: Springer, 1984:21-38.

7. van Loosdrecht MC, Lyklema J, Norde W, Zehnder AJ. Bacterial adhesion: a physicochemical approach. Microbial Ecol 1989;54:75-87.

8. Gibbons RJ. In Schlessinger D, Microbiology. Washington DC: American Society of Microbiology, 1977:395.

9. Fletcher M. In Beachey EH, ed. Bacterial adherence. London: Chapman and Hall, 1980:345.

10. Brown MR, Williams P. Influence of substrate limitation and growth phase on sensitivity to antimicrobial agents. J Antimicrob Chemother 1985;15:7-14.

11. Bryers JD, Characklis WG. Early fouling biofilm formation in a turbulent flow system: overall kinetics. Water Res 1981;15:483-91.

12 Peterson PK, Wilkinson BJ, Kim Y, Schmeling D, Quie PG. Influence of encapsulation on staphylococcal opsonisation and phagocytosis by human polymorphonuclear leucocytes. Infect Immunol 1978;19:943-9.

13. Schwarzmann S, Boring JR. Antiphagocytic effect of slime from a mucoid strain of Pseudomonas aeruginosa. Infect Immunol 1971;3:762-7.

14. Witnak E, Bisno AL, Beachey EH. Hyaluronate capsule prevents attachment of group A streptococci to mouse peritoneal macrophages. Infect Immunol 1981;31:985-91.

15. Govan JR. Mucoid strains of Pseudomonas aeruginosa: the influence of culture medium on the stability of mucus production. J Med Microbiol 1975;8:513-22.

16. Ruseska I, Robbins J, Lashen ES, Costerton JW. Biocide testing against corrosion-causing oilfield bacteria helps control plugging. Oil Gas J 1982:253-64.

17. Nickel JC, Ruseska I, Wright JB, Costerton JW. Tobramycin resistance of Pseudomonas aeruginosa cells growing as a biofilm on urinary tract catheter 
material. Antimicrob Agents Chemother 1985; 27:619-24.

18. Nickel JC, Ruseska I, Whitfield C, Marrie TJ, Costerton JW. Antibiotic resistance to Pseudomonas aeruginosa colonising a urinary catheter in vivo. Eur $\mathbf{J}$ Clin Microbiol 1985;4:213-8.

19. Dasgupta MK, Zubbenbuhler P, Abbi A, Harley FC, Brown NE. Combined evaluation of circulating immune complexes and antibodies to Pseudomonas aeruginosa as an immunologic profile in relation to pulmonary function in cystic fibrosis. J Clin Immunol 1986;7:51-8.

20. Schiotz PO, Jorgensen M, Flensborg EW, Faero O, Husby S, Hoiby $\mathrm{N}$, et al. Chronic Pseudomonas aeruginosa lung infection in cystic fibrosis. Acta Paediatr Scand 1983;72:283-7.

21. Scheld WM, Vaone JA, Sande MA. Bacterial adherence in the pathogenesis of endocarditis: interaction of bacterial dextran, platelets and fibrin. J Clin Invest 1978;61:1394-404.

22. Mills J, Pulliam L, Dall D, Marzouk J, Wilson W, Costerton JW. Exopolysaccharide production by viridans streptococci in experimental endocarditis. Infect Immunol 1984;43:359-67.

23. Nickel JC, Olson ME, McLean RJ, Grant SK, Costerton JW. An ecological study of infected urinary stone genesis in an animal model. Br J Urol 1987; 59:1-10.

24. Bright JJ, Fletcher M. Amino acid assimilation and electron transport system activity in attached and freeliving bacteria. Appl Environ Microbiol 1983; 43:1166-72.

25. Evans DJ, Brown MR, Allison DG, Gilbert P. Susceptibility of bacterial biofilms to tobramycin: role of specific growth rate and phase division cycle. J Antimicrob Chemother 1990;25:585-91.

26. Evans DJ, Allison DG, Brown MR, Gilbert P. Susceptibility of Pseudomonas aeruginosa and Escherichia coli biofilms towards ciprofloxacin: effect of specific growth rate. J Antimicrob Chemother 1991; 27:177-84.

27. Duguid IG, Evans E, Brown MR, Gilbert P. Growth rate independent killing by ciprofloxacin of biofilm derived Staphylococcus epidermidis: evidence for cellcycle dependency. J Antimicrob Chemother 1992; 30:791-802.

28. Gristina AG, Hobgood CD, Webb LX, Myrvik QN. Adhesive colonization of biomaterials and antibiotic resistance. Biomaterials 1987;8:423-6.

29. Prosser BL, Taylor D, Dix BA, Cleeland R. Method of evaluating effects of antibiotics upon bacterial biofilm. Antimicrob Agents Chemother 1987;31:1502-6.

30. Nichols WW, Dorrington SM, Slack MP. Inhibition of tobramycin diffusion by binding to alginate. Antimicrob Agents Chemother 1988;32:518-32.

31. Nichols WW, Evans MJ, Slack MP, Walmsley HL. The penetration of antibiotics into aggregates of mucoid and non-mucoid Pseudomonas aeruginosa. J Gen Microbiol 1989;135:1291-303.

32. Favero MS, Bond WW, Petersen NJ, Cook EH. Scanning electron microscopic study of bacteria resistant to iodophore solutions. In Digenis GA, Ansell J, ed. Proceedings of the International Symposium on Povidone Iodine. University of Kentucky Press, 1983

33. Giwercman B, Jensen ET, Hoiby N, Kharamzi A, Costerton JW. Induction of B-lactamase production in Pseudomonas aeruginosa biofilms. Antimicrob Agents Chemother 1991;35:1008-10.
34. Tuomanen E, Cozens R, Tosch W, Zak O, Tomasz A. The rate of killing of Escherichia coli by B-lactam antibiotics is strictly proportional to the rate of bacterial growth. J Gen Microbiol 1986;132:1297-304.

35. Dagostino L, Goodman AE, Marshall KC. Physiological responses induced in bacteria adhering to surfaces. Biofouling 1991;4:113-9.

36. Bartlett JG, Moon NE, Goldstein PR, Goren B, Onderdonk AB, Polk BF. Cervical and vaginal flora: ecological niches in the female lower genital tract. Am J Obstet Gynecol 1978;130:658-61.

37. Marrie TJ, Harding GK, Ronald AR, Dikkema J, Lam J, Hoban S, Costerton JW. Influence of mucoidy on antibody coating of Pseudomonas aeruginosa. J Infect Dis 1979;139:357-61.

38. Lock MA, Wallace RR, Costerton JW, Ventullo RM, Charlton SE. River epilithon: towards a structural-functional model. Oikos 1984;44:10-22.

39. Obuekwe CO, Westlake DW, Cook FD. Surface changes in mild steel coupons from the action of corrosion-causing bacteria. Appl Environ Microbiol 1981;41:766-74.

40. Hamilton WA. Sulfate reducing bacteria and anaerobic corrosion. Annu Rev Microbiol 1985;39:195-217.

41. Springer EL, Roth IL. The ultrastructure of the capsules of Diplococcus pneumoniae and Klebsiella pneumoniae stained with ruthenium red. J Gen Microbiol 1973;74:21-31.

42. Gristina AG, Costerton JW. Bacteria-laden biofilms: a hazard to orthopaedic prostheses. Infect Surg 1984; 67A:264-73

43. Gristina AG, Price JL, Hobgood CD, Webb LX, Costerton JW. Bacterial colonisation of percutaneous sutures. Surgery 1985;98:12-9.

44. Gristina AG, Costerton JW. Bacterial adherence to biomaterials and tissue. J Bone Joint Surg [Am] 1985;67:264-73.

45. Marrie TJ, Costerton JW. A scanning and transmission electron microscopic study of an infected endocardial pacemaker lead. Circulation 1982;66:1339-43.

46. Marrie TJ, Noble MA, Costerton JW. Examination of the morphology of bacteria adhering to intraperitoneal dialysis catheters by scanning and transmission electron microscopy. J Clin Microbiol 1983;18:1388-98.

47. Marrie TJ, Costerton JW. A scanning and transmission electron microscopic study of the surfaces of intrauterine contraceptive devices. Am J Obstet Gynecol 1983; 146:384-94.

48. Marrie TJ, Costerton JW. Morphology of bacterial attachment to cardiac pacemaker leads and power packs. J Clin Microbiol 1984;19:911-4.

49. Tenney JH, Moody MR, Newman KA, Schimpff SC, Wade JC, Costerton JW, Reed WP. Adherent microorganisms on luminal surfaces of long-term intravenous catheters: importance of Staphylococcus epidermidis in patients with cancer. Arch Intern Med 1986; 146:1949-54.

50. Webb LX, Myers RT, Cordell AR, Hobgood AR, Costerton JW, Gristina AG. Inhibition of bacterial adhesion by antibacterial surface pretreatment of vascular prostheses. J Vasc Surg 1986;4:16-21.

51. Gristina AG, Oga M, Webb LX, Hobgood CD. Adherent bacterial colonisation in the pathogenesis of osteomyelitis. Science 1985;228:991-3.

52. Sherwood DR, Rich WJ, Jacob JS, Hart RJ, Fairchild YL. Bacterial contamination on intraocular and extraocular fluids during extracapsular cataract extraction. Eye 1989;3:308-12.

53. Speaker MG, Milch FA, Shah MK, Eisner W, 
Kreiswirth BN. Role of external flora in the pathogenesis of acute postoperative endophthalmitis. Ophthalmology 1991;98:639-50.

54. Dickey JB, Thompson KD, Jay WM. Anterior chamber aspirate cultures after uncomplicated cataract surgery. Am J Ophthalmol 1991;112:278-82.

55. Puliafito CA, Baker AS, Haaf J, Foster CS. Infectious endophthalmitis: review of 36 cases. Ophthalmology 1982;89:921-9.

56. Olsen JC, Flynn HW, Forster RK, Culbertson WW. Results in the treatment of postoperative endophthalmitis. Ophthalmology 1983;90:692-9.

57. Driebe WT, Mandelbaum S, Forster RK, Schwartz LK, Culbertson WW. Pseudophakic endophthalmitis. Ophthalmology 1986;93:442-8.

58. Fisch A, Salvanet A, Prazuck T, Forestier F, Gerbaud L, Coscas G, Lafaix C. Epidemiology of infective endophthalmitis in France. Lancet 1991;338:1373-6.

59. Vafidis GC, Marsh RJ, Stacey AR. Bacterial contamination of intraocular lens surgery. $\mathrm{Br} \mathrm{J}$ Ophthalmol 1984:68:520-3.

60. Griffiths PG, Elliot TS, McTaggart L. Adherence of Staphylococcus epidermidis to intraocular lenses. $\mathrm{Br} \mathrm{J}$ Ophthalmol 1989;73:402-6.

61. Dilly PN, Holmes-Sellors PJ. Bacterial adhesion to intraocular lenses. J Cataract Refract Surg 1989; 15:317-20.

62. Menikoff JA, Speaker MG, Marmor M, Raskin EM. A case-control study of risk factors for post-operative endophthalmitis. Ophthalmology 1991;98:1761-8.

63. Cusumano A, Busin M, Spitznas $M$. Is chronic intraocular inflammation after lens implantation of bacterial origin? Ophthalmology 1991;98:1703-10.

64. Speaker MG, Menikoff JA. Postoperative endophthalmitis: pathogenesis, prophylaxis and management. Int Ophthalmol Clin 1993;33:51-70.

65. Galentine PG, Cohen EJ, Laibson PR, Adams CD, Michaud R, Arentsen JJ. Corneal ulcers associated with contact lens wear. Arch Ophthalmol 1984; 102:891-4.

66. Alfonso E, Mandelbaum S, Fox MJ, Forster RK. Ulcerative keratitis associated with contact lens wear. Am J Ophthalmol 1986;101:429-33.

67. Mondino BJ, Weissman BA, Farb MD, Petit TH. Corneal ulcers associated with daily-wear and extended-wear contact lenses. Am J Ophthalmol 1986;102:58-65.

68. Schein OD, Ormerod LD, Barraquer E, et al. Microbiology of contact lens-related keratitis. Cornea 1989;8:281-5.

69. Mayo MS, Cook WL, Schlitzer RL, Ward MA, Wilson LA, Ahearn DG. Antibiograms, serotypes, and plasmid profiles of Pseudomonas aeruginosa associated with corneal ulcers and contact lens wear. J Clin Microbiol 1986;24:372-6.

70. Dart JK. Bacterial keratitis in contact lens users [abstract]. BMJ 1987;295:959-60.

71. Dart JK. Contamination of contact lens storage cases. Br J Ophthalmol 1990;74:129-30.

72. Wilson LA, Sawant AD, Simmons RB, Ahearn DG. Microbial contamination of contact lens storage cases and solutions. Am J Ophthalmol 1990;110:193-8.

73. Duran JA, Refojo MF, Gipson IK, Kenyon KR. Pseudomonas attachment to new hydrogel contact lenses. Arch Ophthalmol 1987;105:106-9.

74. John T, Refojo MF, Hanninen L, Leong FL, Medina A, Kenyon KR. Adherence of viable and non-viable bacteria to soft contact lenses. Cornea 1989;8:21-33.

75. Aswad MI, John T, Braza M, Kenyon K, Baum J.
Bacterial adherence to extended wear soft contact lenses. Ophthalmology 1990;97:296-302.

76. Slusher MM, Myrvik QN, Lewis JC, Gristina AG. Extended-wear lenses, biofilm, and bacterial adhesion. Arch Ophthalmol 1987;105:110-5.

77. Miller MJ, Ahearn DG. Adherence of Pseudomonas aeruginosa to hydrophilic contact lenses and other substrata. J Clin Microbiol 1987;25:1392-7.

78. Stapleton F, Dart JKG, Matheson M, Woodward GE. Bacterial adherence and glycocalyx formation on unworn hydrogel lenses. $\mathrm{J} \mathrm{Br}$ Contact Lens Assoc 1993;16:113-7.

79. Dart JK, Peacock J, Grierson I, Seal DV. Ocular surface, contact lens and bacterial interactions in a rabbit model. In Transactions of BCLA Conference, Birmingham, 1988:95-6.

80. Holland S, Ruseska I, Alfonso E, et al. Pseudomonas and extended wear contact lenses. Invest Ophthalmol Vis Sci (Suppl) 1988;11:278.

81. Stapleton F, Dart JKG, Davies S. Bacterial adherence and biofilm formation. Invest Ophthalmol Vis Sci (Suppl) 1991;32:366.

82. Radford CF, Stapleton F, Minassian DC, Dart JK. The increased risk of microbial keratitis associated with soft contact lens use and inadequate lens care. Invest Ophthalmol Vis Sci (Suppl) 1993;34:1361.

83. Gristina AG, Jennings RA, Naylor PT, Myrvik QN, Webb LX. Comparative in vitro antibiotic resistance of surface colonising coagulase negative staphylococci. Antimicrob Agents Chemother 1989;33:813-6.

84. Reiss GR, Campbell RJ, Bourne WM. Infectious crystalline keratopathy. Surv Ophthalmol 1986; 31:69-72.

85. Meisler DM, Langston RH, Naab TJ, Aaby AA, McMahon JT, Tubbs RR. Infectious corneal crystalline formation. Am J Ophthalmol 1984;97:337-43.

86. Gorovoy MS, Stern GA, Hood CI, Allen C. Intrastromal noninflammatory bacterial colonisation of a corneal graft. Arch Ophthalmol 1983;101:1749-52.

87. Hunts JH, Matoba AY, Osato MS, Font RL. Infectious crystalline keratopathy: the role of bacterial exopolysaccharide. Arch Ophthalmol 1993;111:528-30.

88. McDonnell JM, Gritz DC, Hwang D, McDonnell PJ. Infectious crystalline keratopathy with ring opacity. Cornea 1992;11:479-83.

89. Patitsas C, Rockwood EJ, Meisler DM, McMahon JT. Infectious crystalline keratopathy occurring in an eye subsequent to glaucoma filtering surgery with postoperative subconjunctival 5-fluorouracil. Ophthalmic Surg 1991;22:412-3.

90. Wilhelmus KR, Robinson NM. Infectious crystalline keratopathy caused by Candida albicans. Am J Ophthalmol 1991;112:322-5.

91. Ormerod LD, Ruoff KL, Meisler DM, Wasson PJ, Kintner JC, Dunn SP, et al. Infectious crystalline keratopathy: role of nutritionally variant streptococci and other bacterial factors. Ophthalmology 1991;98:159-69.

92. Klintner JC, Grossniklaus HE, Lass JH, Jacobs G. Infectious crystalline keratopathy associated with topical anesthetic abuse. Cornea 1990;9:77-80.

93. Lam S, Meisler DM, Krachmer JH. Enterococcal infectious crystalline keratopathy. Cornea 1993; $12: 273-6$.

94. Lubniewski AJ, Houchin KW, Holland EJ, Weeks DA, Wessels IF, McNeill JI, Cameron JD. Posterior infectious crystalline keratopathy with Staphylococcus epidermidis. Ophthalmology 1990;97:1454-9. 
95. Goswami SK, Kivity S, Marom Z. Erythromycin inhibits respiratory glycoconjugate secretion from human airways in vitro. Am Rev Respir Dis 1990; 141:72-8.

96. Nagai H, Shishido H, Yoneda R, Yamaguchi E, Tamura A, Kurashima A. Long-term low-dose administration of erythromycin to patients with diffuse panbronchiolitis. Respiration 1991;58:145-9.
97. Yasuda H, Ajiki Y, Koga T, Kawada H, Yokota T. Interactions between biofilms formed by Pseudomonas aeruginosa and clarithromycin. Antimicrob Agents Chemother 1993;37:1749-55.

98. Dall L, Barnes WG, Lane JW, Mills J. Enzymatic modification of glycocalyx in the treatment of experimental endocarditis due to viridans streptococci. J Infect Dis 1987;156:736-40. 